\title{
UPAYA MENINGKATKAN HASIL BELAJAR GEOGRAFI MELALUI METODE KERJA KELOMPOK KELAS XI IIS3 SMAN 1 MENJALIN
}

\author{
Suyono \\ SMA Negeri 1 Menjalin Kabupaten Landak \\ Email: sudiyono.sman1menjalin@gmail.com
}

\begin{abstract}
Abstrak
Upaya Meningkatkan Hasil Belajar Siswa Melalui Metode Kerja Kelompok pada Mata Pelajaran Geografi Materi Sebaran dan Pengelolaan Sumber Daya Alam di Indonesia pada Kelas XI IIS 3 SMA Negeri 1 Menjalin Kabupaten Landak. Penelitian ini bertujuan untuk mengetahui penerapan metode Kerja kelompok dengan kerja kelompok terhadap hasil belajar siswa pada mata pelajaran Geografi di kelas XI IIS 3 SMA Negeri 1 Menjali Kabupaten Landak. Metode penelitian yang digunakan dalam penelitin ini adalah penelitian tindakan (action research). Adapun bentuk penelitian yang digunakan dalam penelitian ini adalah penelitian tindakan kelas (classroom action research). (1) Pembelajaran dengan pembelajaran dengan gabungan metode Kerja kelompok dengan kerja kelompok pada materi pelajaran memiliki dampak positif dalam meningkatkan prestasi belajar siswa yang ditandai dengan peningkatan ketuntasan belajar siswa dalam setiap siklus, yaitu siklus I 17 orang (54,55\%), siklus II 28 orang (84.84 \%), (2) Pembelajaran gabungan metode Kerja kelompok dengan kerja kelompok pada materi pelajaran efektif untuk mengingatkan kembali materi ajar yang telah diterima siswa selama proses pembelajaran, sehingga mereka merasa siap untuk menghadapi ulangan umum bersama .
\end{abstract}

\section{Kata kunci: Kerja kelompok, Hasil Belajar dan Geografi}

\section{PENDAHULUAN}

Dalam upaya peningkatan kualitas sekolah, tenaga kependidikan yang meliputi, tenaga pendidik, pengelola satuan pendidikan, penilik, pengawas, peneliti, teknis sumber belajar, sangat diharapkan berperan sebagaimana mestinya dan sebagai tenaga kependidikan yang berkualitas. Tenaga pendidik atau guru yang berkualitas adalah tenaga pendidik atau guru yang sanggup, dan terampil dalam melaksanakan tugasnya.

Proses pembelajaran yang dilakukan guru memang dibedakan keluasan cakupannya, tetapi dalam konteks kegiatan belajar mengajar mempunyai tugas yang sama. Maka tugas mengajar bukan hanya sekedar menuangkan bahan pelajaran, tetapi teaching is primarily and always the stimulation of learner (Wetherington, 1986: 131-136), dan mengajar tidak hanya dapat dinilai dengan hasil penguasaan mata pelajaran, tetapi yang terpenting adalah perkembangan peribadi anak, sekalipun mempelajari pelajaran yang baik, akan memberikan pengalaman membangkitkan bermacam-macam sifat, sikap dan kesanggupan yang konstruktif.

Dengan tercapainya tujuan dan kualitas pembelajaran, maka dikatakan bahwa guru telah berhasil dalam mengajar. Keberhasilan kegiatan belajar mengajar tentu saja diketahui setelah diadakan evalusi dengan berbagai faktor yang sesuai dengan rumusan beberapa tujuan pembelajaran. Sejauh mana tingkat keberhasilan belajar mengajar, dapat dilihat dari daya serap anak didik dan persentase keberhasilan anak didik dalam mencapai tujuan pembelajaran khusus. Jika hanya tujuh puluh lima persen $(75 \%)$ atau lebih dari jumlah anak didik yang mengikuti proses belajar mengajar mencapai taraf keberhasilan kurang (di bawah taraf minimal), maka proses belajar mengajar berikutnya hendaknya ditinjau kembali. 
Setiap sebelum mengajar, guru perlu membuat persiapan mengajar dalam rangka melaksanakan sebagian dari rencana bulanan dan rencana tahunan. Dalam persiapan itu sudah terkandung tentang; tujuan mengajar, pokok yang akan diajarkan, metode mengajar, bahan pelajaran, alat peraga dan teknik evaluasi yang digunakan. Karena itu setiap guru harus memahami benar tentang tujuan mengajar, secara khusus memilih dan menentukan metode mengajar sesuai dengan tujuan yang hendak dicapai, cara memilih, menentukan dan menggunakan alat peraga, cara membuat tes dan menggunakannya, dan pengetahuan tentang alat-alat evaluasi. Oleh sebab itu, teknologi pembelajaran adalah salah satu dari aspek tersebut yang cenderung diabaikan oleh guru, terutama bagi mereka yang menganggap bahwa sumber daya manusia pendidikan, sarana dan prasarana pendidikan tidaklah terlalu penting. Padahal kalau dikaji lebih lanjut, setiap pembelajaran pada semua tingkat pendidikan baik formal maupun non-formal apalagi tingkat Sekolah Dasar, haruslah berpusat pada kebutuhan perkembangan anak sebagai calon individu yang unik, sebagai makhluk sosial, dan sebagai calon manusia seutuhnya.

Hal tersebut dapat dicapai apabila dalam aktivitas belajar mengajar, guru senantiasa memanfaatkan teknologi pembelajaran yang mengacu pada gabungan metode Kerja kelompok dengan metode kerja kelompok dalam penyampaian materi agar mudah diserap peserta didik atau siswa yang memiliki kemampuan yang berbeda.Khususnya dalam pembelajaran Ilmu Pengetahuan Sosial, agar siswa dapat memahami materi yang disampaikan guru dengan baik, maka proses gabungan metode Kerja kelompok dengan metode kerja kelompok, guru akan memulai membuka pelajaran dengan menyampaikan kata kunci, tujuan yang ingin dicapai.

Tujuan umum penelitiaian ini adalah untuk mengetahui siklus yang baik mengenaipenerapan metode Kerja kelompok terhadap hasil belajar siswa pada mata pelajaran Geografi di kelas XI IIS 3 SMA Negeri 1 Menjalin Kabupaten Landak.
Adapun sub tujuan penelitian ini adalah untuk mengetahui: (1) Perencanaan pembelajaran Geografi di kelas XI IIS 3 SMA Negeri 1 Menjalin Kabupaten Landak, (2) Pelaksanaan metode Kerja kelompok dengan metode kerja kelompok terhadap motivasi belajar siswa dalam pembelajaran Geografi di kelas XI IIS 3 SMA Negeri 1 Menjalin Kabupaten Landak, (3) Hasil belajar siswa setelah melaksanakan metode Kerja kelompok dalam pembelajaran Geografi di kelas XI IIS 3 SMA Negeri 1 MenjalinKabupaten Landak.

Manfaat bagi siswa: (1) Tumbuhnya motivasi siswa dalam proses pembelajaran, (2) Meningkatkan hasil belajar siswa baik aspek Kognitif maupun apektif, (3) Meningkatkan Keberanian bertanya siswa dalam pembelajaran, (3) Meningkatkan keaktifan siswa dalam belajar. Manfaat bagi guru: (1) Mengetahui strategi pembelajaran yang bervariasi untuk memperbaiki dan menigkatkan mata pelajaran Geografi, (2) Diperolehnya strategi pembelajaran yang tepat untuk materi Sebaran dan pengelolaan sumber daya alam di indonesia, (3) Diperolehnya media pembelajaran yang cocok untuk pembejaran Geografi dalam usaha meningkatkan ketaqwaan terhadap Tuhan Yang Maha Esa. Manfaat bagi Sekolah: (1) Meningkatkan hasil belajar siswa dalam pemnelajaran, (2) Tumbuhnya motivasi guru dan siswa dalam mengembangkan proses pembelajaran yang bermutu, (3) Tumbuhnya iklim pembelajaran siswa aktif di Sekolah, (3) Meningkatkan keaktifan guru dalam mengembangkan proses pembelajaran.

\section{METODE PENELITIAN}

Metode penelitian yang digunakan dalam penelitin ini adalah penelitian tindakan (action research), karena penelitian dilakukan untuk memecahkan masalah pembelajaran di kelas. Penelitian ini juga termasuk penelitian deskriptif, sebab menggambarkan bagaimana suatu teknik pembelajaran diterapkan dan bagaimana hasil yang diinginkan dapat dicapai. Adapun bentuk penelitian yang digunakan dalam penelitian ini adalah penelitian tindakan kelas ( classroom action research) 
Menurut Oja dan Sumarjan (dalam Titik Sugiarti, 1997: 8) mengelompokkan penelitian tindakan menjadi empat macam yaitu, (a) guru sebagai peneliti, (b) penelitian tindakan kolaboratif; (c) simultan terintegratif; (d) administrasi sosial eksperimental. Dalam penelitian tindakan ini menggunakan pendekatan tindakan kolaboratif. Dimana guru sebagai peneliti, penanggung jawab penuh penelitian ini. Tujuan utama dari penelitian tindakan ini adalah untuk meningkatkan hasil pembelajaran di kelas dimana guru secara penuh terlibat dalam penelitian mulai dari perencanaan, tindakan, pengamatan, dan refleksi. Penelitian ini menggunakan Penelitian Tindakan Kelas (PTK). Menurut Tim Pelatih Proyek PGSM, PTK adalah suatu bentuk kajian yang bersifat reflektif oleh pelaku tindakan yang dilakukan untuk meningkatkan kemantapan rasional dari tindakan mereka dalam melaksanakan tugas, memperdalam pemahaman terhadap tindakan-tindakan yang dilakukan itu, serta memperbaiki kondisi dimana praktek pembelajaran tersebut dilakukan (dalam Mukhlis, 2000: 3). Sedangkah menurut Mukhlis (2000: 5) PTK adalah suatu bentuk kajian yang bersifat sistematis reflektif oleh pelaku tindakan untuk memperbaiki kondisi pembelajaran yang dilakukan.

Adapun tujuan utama dari PTK adalah untuk memperbaiki/meningkatkan pratek pembelajaran secara berkesinambungan, sedangkan tujuan penyertaannya adalah menumbuhkan budaya meneliti di kalangan guru (Mukhlis, 2000: 5).Dalam penelitian ini peneliti bekerjasama dengan teman sejawat, kehadiran peneliti sebagai guru di kelas sebagai pengajar tetap dan dilakukan seperti biasa, sehingga siswa tidak tahu kalau diteliti. Dengan cara ini diharapkan didapatkan data yang seobjektif mungkin demi kevalidan data yang diperlukan.

Alat pengumpulan data yang digunakan dalam penelitian ini adalah: (1) Observasi Langsung. Observasi langsung dilakukan pada saat proses pembelajaran berlangsung, (2) Teknik Pengukuran. Teknik pengukuran merupakan teknik pengukuran data yang dilakukan untuk mengukur hasil belajar siswa. Alat pengumpul data dalam penelitian ini yang relevan berdasarkan teknik pengumpulan data: Lembar obrsevasi adalah alat yang digunakan untuk mengukur hasil belajar siswa secara langsung, dan Tes hasil belajar adalah tes kemampuan siswa, dalam menerima materi pelajaran yang diharpkan sesuai dengan rencana pelaksanaan pembelajaran dengan menggunakan bentuk tes pilihan ganda.

Analisis data dilakukan untuk menganalisis tingkat keberhasilan atau persentase keberhasilan siswa setelah proses belajar mengajar setiap putarannya dilakukan dengan cara memberikan evaluasi berupa soal tes tertulis pada setiap akhir putaran. Analisis ini dihitung dengan menggunakan statistik sederhana yaitu: (1) untuk menilai ulangan atau tes formatif, (2) Untuk ketuntasan belajar. Ada dua kategori ketuntasan belajar yaitu secara perorangan dan secara klasikal. Berdasarkan petunjuk pelaksanaan belajar mengajar kurikulum 1994 (Depdikbud, 1994), yaitu seorang siswa telah tuntas belajar bila telah mencapai skor $75 \%$ atau nilai 75 , dan kelas disebut tuntas belajar bila di kelas tersebut terdapat $85 \%$ yang telah mencapai daya serap lebih dari atau sama dengan $75 \%$. Untuk menghitung persentase ketuntasan belajar digunakan rumus sebagai berikut: Indikator penelitian ini dianggap berhasil jika ketuntasan belajar $\geq 75 \%$

Sesuai dengan jenis penelitian yang dipilih, yaitu penelitian tindakan, maka penelitian ini menggunakan model penelitian tindakan dari Kemmis dan Taggart (dalam Sugiarti, 1997: 6), yaitu berbentuk spiral dari siklus yang satu ke siklus yang berikutnya. Setiap siklus meliputi planning (rencana), action (tindakan), observation (pengamatan), dan reflection (refleksi). Langkah pada siklus berikutnya adalah perncanaan yang sudah direvisi, tindakan, pengamatan, dan refleksi. Sebelum masuk pada siklus 1 dilakukan tindakan pendahuluan yang berupa identifikasi permasalahan. Dalam pelaksanaan penelitian tindakan ini penulis membuat sebanyak 2 siklus, dimana setiap siklus menyimpulkan hasil refleksi yang dapat 
menghasilkan tujuan pembelajaran yang diharapkan, yaitu mencapai tingkat $75 \%$ keatas.
Siklus spiral dari tahap-tahap penelitian tindakan kelas dapat dilihat pada gambar berikut:

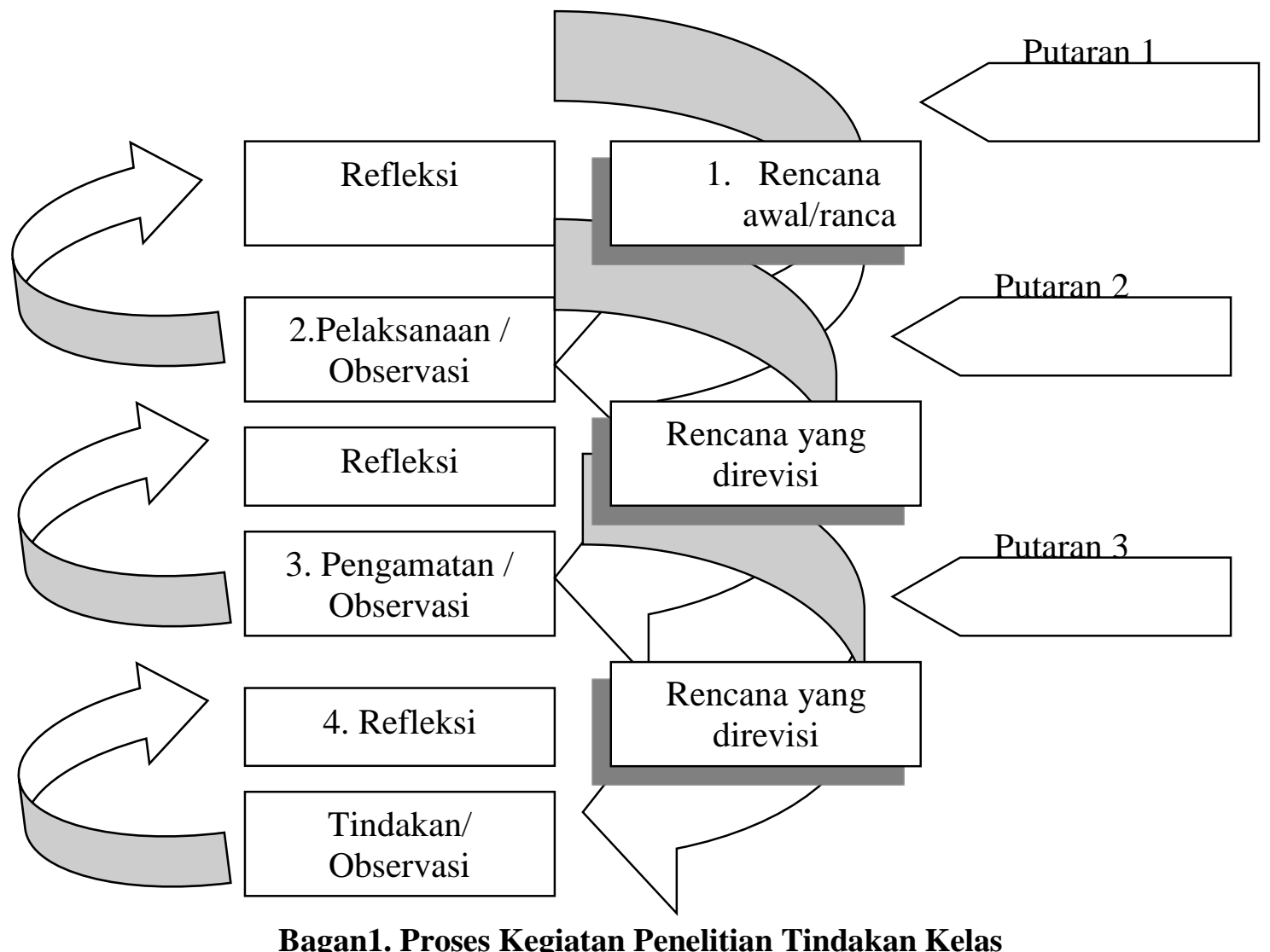

Tahapan-tahapan penelitian yang akan dilaksanakan dibagi dalam 4 tahap: (1) Perencanaan adalah sebelum penelitian dilakukukan, peneliti melakukan pengamatan proses pembelajaran di kelas dan melihat hasil belajar siswa. Berdasarkan hasil pengamatan dan analisis hasil belajar maka guru membuat perangkat pembelajaran yang mendukung proses penelitian yang akan dilakukan. Perangkat pembelajaran yang harus dipersiapkan antara lain : Rencana Pelaksanaan Pembelajaran, Media Pembelajaran, instrument penilaian, Bahan Ajar, aktivitas belajar mengajar, (2) Pelaksanaan adalah setelah perangkat pembelajaran telah disiapkan dengan lengkap dan baik maka tahap berikutnya adalah menaksanakan proses pembelajaran sesuai dengan sekenario pembelajaran yang telah direncanakan.
Adapun pelaksanakan pembelajaran yang akan dilaksanakan pada saat penelitian sebagai berikut: Kegiatan Awal, Kegiatan Inti, Kegiatan Penutup, (3) Observasi adalah Observasi dalam penelitian ini dilakukan dilakukan oleh teman sejawat. Observasi yang dilakukan untuk melihat bagaimana proses pembelajaran Metode Kerja Kelompok dikelas XII IPA1 SMA Negeri 1 Menjalin Kabupaten Landak. Observasi dilakukan beerdasarkan pedoman observasi yang dibuat untuk tujuan penelitian ini. Lembar observasi bisa mengacu kepada APKG2 atau Lembar Observasi yang dikembangkan sendiri oleh peneliti berdasarkan rancangan pembelajaran yang telah di susun, (4) Refleksi adalah untuk mengetahui secara detail pembelajaran Metode Caramah. Observer berdiskusi untuk menganalisis kekurangan proses pembelajaran yang telah dilakukan dan 
merumuskan perbaikan proses pembelajaran untuk siklus berikutnya:

\section{HASIL DAN PEMBAHASAN Hasil Penelitian}

Penelitian ini bertujuan untuk mengetahui penerapan metode kerja kelompok terhadap hasil belajar siswa pada mata pelajaran matematika kelas XI IIS IPS 3 SMA Negeri 1 Menjalin Kabupaten Landak. Berdasarkan skor yang diperoleh: Peningkatan hasil belajar siswa dengan penggunaan metode kelompok dalam pembelajaran Matematika di kelas XI IIS 3 SMA Negeri 1 Menjalin Kabupaten Landak sebagai berikut: (1) Pratindakan 38,63\%. Dari 44 siswa terdapat 17 siswa yang telah mencapai nilai diatas 75 , dan terdapat 27 siswa yang belum mencapai nilai 75 , (2) Siklus I sebesar 45,50\%. Dari 44 siswa terdapat 20 siswa yang telah mencapai nilai diatas 75 , dan terdapat 24 siswa yang belum mencapai nilai 75, (3) Siklus II sebesar $84,55 \%$. Dari 44 siswa terdapat 36 siswa yang telah mencapai nilai diatas 75 , dan terdapat 6 siswa yang belum mencapai nilai 75 .

Tabel 1

Data Hasil Penelitian Siklus 1 dan Siklus 2

\begin{tabular}{cccccccc}
\hline \multirow{2}{*}{ No } & $\begin{array}{c}\text { Hasil } \\
\text { Belajar } \\
\text { Siswa }\end{array}$ & \multicolumn{2}{c}{ Pra Tindakan } & \multicolumn{2}{c}{ Siklus I } & Siklus II \\
\cline { 3 - 8 } & Jumlah & Prosentase & Jumlah & Presentase & Jumlah & Presentase \\
\hline 1 & Tuntas & 17 & $38,63 \%$ & 20 & $45,45 \%$ & 36 & $84,84 \%$ \\
\hline 2 & $\begin{array}{c}\text { Belum } \\
\text { Tuntas }\end{array}$ & 27 & $61.36 \%$ & 24 & $54,55 \%$ & 8 & $15,16 \%$ \\
\hline & Jumlah & 44 & $100 \%$ & 44 & $100 \%$ & 44 & $100 \%$ \\
\hline
\end{tabular}

\section{Pembahasan Penelitian}

Untuk mengetahui kemampuan awal siswa maka dilakukan tes pra tindakan, kemudian dilakukan analisis untuk menghitung rata-rata. Hasil pra tindakan diperoleh nilai rata sebesar 38,63\%. Dari 44 siswa terdapat $17(38,63 \%)$ siswa yang telah mencapai nilai diatas 75 , dan terdapat 27 $(61,36 \%)$ siswa yang belum mencapai nilai 75.

Data hasil belajar pada siklus I (setelah dilaksanakan metode kelompok dapat diketahui bahwa dari 44 siswa terdapat 20 Orang $(45,45 \%)$ siswa yang mencapai ketuntasan belajar. Sedangkan siswa yang belum mencapai ketuntasan belajar berjumlah 24 orang $(54,55 \%)$.

Data hasil belajar pada siklus II dapat diketahui bahwa dari 44 siswa terdapat 36 Orang $(84,84 \%)$ siswa yang telah mencapai nilai diatas 75 . Sedangkan siswa yang belum mencapai ketuntasan belajar berjumlah 8 orang $(15,16 \%)$ siswa yang belum mencapai nilai diatas 75 .
Berdasarkan hasil observasi pelaksanaan kegiatan belajar pada siklus I ini masih terdapat kekurangan-kekurangan. Maka perlu adanya revisi untuk dilaksanakan pada siklus II antara lain: (1) Guru dalam memotivasi siswa hendaknya dapat membuat siswa lebih termotivasi selama proses belajar mengajar berlangsung, (2) Guru harus lebih dekat dengan siswa sehingga tidak ada perasaan takut dalam diri siswa baik untuk mengemukakan pendapat atau bertanya, (3) Guru harus lebih sabar dalam membimbing siswa merumuskan kesimpulan/menemukan konsep, (4) Guru harus mendistribusikan waktu secara baik sehingga kegiatan pembelajaran dapat berjalan sesuai dengan yang diharapkan, (5) Guru sebaiknya menambah lebih banyak contoh soal dan memberi soal-soal latihan pada siswa untuk dikerjakan pada setiap kegiatan belajar mengajar

Sedangkan untuk aktivitas guru selama pembelajaran telah melaksanakan langkahlangkah pembelajaran kooperatif model Kerja kelompok dengan baik. Hal ini terlihat dari 
aktivitas guru yang muncul di antaranya aktivitas membimbing dan mengamati siswa dalam mengerjakan kegiatan, menjelaskan materi yang tidak dimengerti siswa, memberi umpan balik, evaluasi maupun tanya jawab dimana persentase untuk aktivitas di atas cukup besar

Pelaksanaan kegiatan belajar mengajar pada siklus II ini masih terdapat kekurangan, sehingga perlu adanya refisi untuk dilakukan pada siklus berikutnya. (1) Guru perlu lebih terampil dalam memotivasi siswa dan lebih jelas dalam menyampaikan tujuan pembelajaran. Dimana siswa diajak untuk terlibat langsung dalam setiap kegiatan yang akan dilakukan, (2) Guru perlu mendistribusikan waktu secara baik dengan menambahkan informasi-informasi yang dirasa perlu dan memberi catatan, (3) Guru harus lebih terampil dan bersemangat dalam memotivasi siswa sehingga siswa bisa lebih antusias.

Bersdasarkan uraian diatas, maka dari segi hasil evaluasi yang diperoleh siswa sudah mencapai indikator kinerja yang ditetapkan. Demikian juga dengan ketuntasan skenario pembelajaran yang ditetapkan guru telah mencapai indicator kinerja dari segi proses. Jadi dapat disimpulkan bahwa pembelajaran Geografi melalui model Kerja kelompok dapat meningkatkan hasil belajar siswa kelas XI IIS 3 SMA Negeri 1 Menjalin Kabupaten Landak.

\section{SIMPULAN DAN SARAN Simpulan}

Berdasarkan seluruh pembahasan serta analisis yang telah dilakukan dapat disimpulkan sebagai berikut: (1) Pembelajaran dengan pembelajaran dengan gabungan metode Kerja kelompok dengan kerja kelompok pada materi pelajaran memiliki dampak positif dalam meningkatkan prestasi belajar siswa yang ditandai dengan peningkatan ketuntasan belajar siswa dalam setiap siklus, yaitu siklus I 17 orang $(54,55 \%)$, siklus II 28 orang ( $84.84 \%)$, Pembelajaran dengan gabungan metode Kerja kelompok dengan kerja kelompok pada materi pelajaran mempunyai pengaruh positif, yaitu dapat meningkatkan motivasi belajar siswa yang ditunjukan dengan rata-rata jawaban siswa yang menyatakan bahwa siswa tertarik dan berminat dengan pembelajaran dengan gabungan metode Kerja kelompok dengan kerja kelompok pada materi pelajaran sehingga mereka menjadi termotivasi untuk belajar, (2) Pembelajaran gabungan metode Kerja kelompok dengan kerja kelompok pada materi pelajaran efektif untuk mengingatkan kembali materi ajar yang telah diterima siswa selama proses pembelajaran, sehingga mereka merasa siap untuk menghadapi ulangan umum bersama .

\section{Saran-Saran}

Agar proses belajar mengajar di kelas lebih efektif dan lebih memberikan hasil yang optimal bagi siswa, maka disampaikan saran sebagai berikut: (1) Bagaimana melaksanakan pembelajaran dengan gabungan metode Kerja kelompok dengan kerja kelompok pada materi pelajaran memerlukan persiapan yang cukup matang, sehingga guru harus mampu menentukan atau memilih topik yang benarbenar bisa diterapkan dengan pembelajaran dengan gabungan metode Kerja kelompok dengan kerja kelompok pada materi pelajaran proses belajar mengajar sehingga diperoleh hasil yang maksimal, (2) Untuk meningkatkan prestasi belajar siswa, guru hendaknya sering melatih siswa dengan berbagai metode, dimana siswa nantinya dapat menemukan pengetahuan baru, memperoleh konsep dan keterampilan, sehingga siswa berhasil atau mampu memecahkan masalah-masalah yang dihadapinya.

\section{DAFTAR PUSTAKA}

Arikunto, Suharsimi dkk. (2006). Penelitian Tindakan Kelas. Jakarta: Bumi Aksara.

Bobbi. DePorter . (2009).Quantum Writer Menulis Dengan Mudah, Fun, dan Hasil Memuaskan. Jakarta: Kaifa. ..2010. Quantum Learning. Bandung: Kaifa.

Caca, Sudarsa dkk. 1992. Surat Menyurat Dalam Bahasa Indonesia. Jakarta: Pusat Pembinaan dan Pengembangan Bahasa. 
Ferdiansyah, dan Abitur A. P. 2007. Mari Membuat Surat. Pontianak: Wpp.

Hernowo. 2003. Quantum Writing. Bandung: MiC.

Nurgiyantoro, Burhan. 2001. Penilaian dalam Pengajaran Bahasa dan Sastra Indonesia. Yogyakarta: BPFE.

Sagala, S. 2003. Konsep dan Makna Pembelajaran: Untuk Membantu Memecahkan Problematika Belajar dan Mengajar. Bandung: Alfabeta.

Soewito, dkk 1980. Surat Menyurat Indonesia. Jakarta: Departemen Pendidikan dan kebudayaan.

Subagyo Heni.1997. Surat Menyurat. Surabaya: Amelia Surabaya.
Sudjana, Nana. 2006. Penilaian Hasil Proses Belajar Mengajar. Bandung: Remaja Rosdakarya.

Sukino. 2010. Menulis itu Mudah. Menulis itu Mudah. Yogyakarta: Pustaka Populer LKIS.

Surakhmad, W. 1979. Metodologi Pengajaran Nasional. Bandung: Jemmars.

Susetyo. 2009. Menulis Akademik. Bengkulu: FKIP UNIB.

Suyatno. 2004. Teknik Pembelajaran Bahasa dan Sastra. Surabaya: SIC.

Tarigan Henry Guntur. 1994. Menulis Sebagai Suatu Keterampilan Berbahasa. Bandung: Angkasa. 